Semina $\square \quad \mathrm{Nr} 16$

Scientiarum 2017

s. $241-254$

DOI: http://dx.doi.org/10.15633/ss.2494

Dariusz Adam Szkutnik

\title{
O współczesnych badaniach obejmujących zakres stanowiska neowitalistycznego Hansa Driescha. Ogólne uwagi krytyczne
}

Hans Driesch (1867-1941) to niemiecki embriolog i filozof, oceniany krytycznie głównie za poglądy spekulatywno-metafizyczne. Był twórca słynnych eksperymentów embriologicznych, ześrodkowanych wokół pojęcia entelechii.

Zamierzeniem badawczym autora jest wykazanie, że stanowisko neowitalistyczne Driescha wymaga dodatkowej, pogłębionej analizy metodologicznej, uwzględniającej podstawowe czynności poznawcze filozofa o charakterze ściśle naukowym, a nie tylko metafizycznym, tj. tworzenie niezbędnych pojęć, planowanie i przeprowadzanie badań eksperymentalnych oraz naukowych uogólnień teoretycznych w zakresie morfogenezy, zmierzających do uwydatnienia swoistości jakościowej zjawisk organicznych w przyrodzie. Driesch czynił to na zasadzie przekuwania treści określonych pojęć filozoficznych, głównie entelechii, na odpowiednie czynności poznawcze.

\section{O tym, czym się zajmują badacze i filozofowie, analizując stanowisko neowitalistyczne Hansa Driescha}

Chociażby krótki i pobieżny przegląd podstawowych pozycji bibliograficznych dotyczacych stanowiska Driescha pokazuje, że mają one $\mathrm{z}$ reguły charakter analiz historyczno-porównawczych. Ponadto do- 
tykają stanowiska Driescha w wymiarze metafizycznym, a nie w odniesieniu do metodologii jego badań morfogenetycznych i biologicznych, o ile były one inspirowane ideami witalistycznymi. W efekcie autorzy wspomnianych analiz nie sa także do końca świadomi rosnacego czysto spekulatywnego charakteru jego dywagacji teoretycznych w miarę oddalania się od ich doświadczalnego fundamentu. Nieświadomość owa skutkuje tym, że niesłusznie oddzielają oni naukowo-badawczą pracę eksperymentalną Driescha od jego późniejszych rozważań spekulatywno-metafizycznych, niemieszczących się w ogólnym obszarze szeroko pojętej metodologii nauki.

Niektórzy historycy filozofii i nauki błędnie pojmowali stanowisko Driescha. Praca Driescha na polu biologii i filozofii bywała mylnie rozumiana jako tylko czysta metafizyka. Przyczyną takiego stanu rzeczy wydają się zbyt fragmentaryczne analizy poszczególnych głównych etapów pracy badawczej Driescha. Przesadnie zwracano uwagę na czasowo późniejszy aspekt metafizyczno-spekulatywny dociekań Driescha, nie dostrzegając lub co najmniej pomniejszając znaczenie o wiele wcześniejszego etapu naukowo-badawczego i metodologiczno-epistemologicznego w praktykowaniu przez Driescha koncepcji witalistycznej w embriologii. Nic dziwnego, że takie zawężenie pola analizy w odniesieniu do stanowiska Driescha w konsekwencji mogło doprowadzać do przesadnego uwydatniania samej tylko metafizyki, szczególnie entelechii jako pozaprzestrzennego bytu niekwantywnego.

Poniżej autor przedstawi ważniejsze pozycje monograficzne dotyczące - częściowo lub w całości - stanowiska i poglądów Hansa Driescha.

Najobszerniejsza monografia dotycząca wielowątkowego stanowiska Driescha jest autorstwa Horsta Freyhofera: The Vitalism of Hans Driesch. The Success and Decline of a Scientific Theory ${ }^{1}$. Ksiażka ta jest opracowaniem, w którym autor starał się pokazać adekwatność witalizmu Driescha w stosunku do teorii wiedzy w ogóle, a nawet do antropologii filozoficznej i etyki. Niewiele jest w niej od-

1 Zob. H. Freyhofer, The Vitalism of Hans Driesch. The Success and Decline of a Scientific Theory, Frankfurt am Main 1982. 
niesień do związków metodologicznych, które łączą jego teorię witalistyczną z realizowanym przezeń doświadczeniem. Autor uzasadnia, dlaczego Driesch wybrał takie, a nie inne założenia badawcze, a odrzucił równie ważne, chociaż już sprzeczne z jego zapatrywaniem witalistycznym. Praca ta obejmuje cały zakres materiału badawczego w sposób bardzo ogólny. Dotyczy szczególnie okresu działalności Driescha w fazie wczesnych badań eksperymentalnych do momentu sprecyzowania pojęcia entelechii.

W moim przekonaniu omawiana praca w ogóle nie dotyczy metodologii badań morfogenetycznych Driescha, a na pewno nie przedstawia jej w sposób kompleksowy i wyczerpujący. Pierwsza część książki prezentuje bowiem tylko w sposób pobieżny odrzucenie przez Driescha mechanicyzmu w biologii; druga część zawiera ujęcie witalizmu Driescha jako ogólnej teorii przyrody; trzecia część monografii odnosi się do ujęcia witalizmu Driescha jako teorii człowieka, czyli antropologii filozoficznej; czwarta część dotyczy witalizmu jako teorii Boga; wreszcie piąta część pracy obejmuje odniesienie witalizmu Driescha do różnych działów nauki (teoria względności w fizyce i parapsychologia) i do kwestii społecznych (np. do faszyzmu). Najbliższe problematyce naukowo-biologicznej ujęcie zawarte we wskazanej drugiej części nie dotyczy w ogóle szczegółowej problematyki metodologicznej badań naukowych Driescha, która zasługuje na pełne dowartościowanie oraz szczegółowe omówienie.

Publikacja Reinharda Mocka Wilhelm Roux-Hans Driesch. Zur Geschichte der Entwicklungsphysiologie der Tiere ${ }^{2}$ zawiera porównanie stanowiska Driescha ze stanowiskiem Wilhelma Roux, znanego zwolennika mechanicyzmu w biologii. Z całokształtu badań i rozważań Driescha, nie licząc biografii, prezentowana jest w zarysie tylko jego filozofia, a z rozważań obejmujących Przyczynek do problematyki witalizmu w punkcie „b) Vitalismus und biologische Vorschung" mamy zaledwie niecałe dwie strony tekstu! Tyle poświęcono badaniom naukowym Driescha i stosowanej w nich metodologii.

2 Zob. R. Mocek, Wilhelm Roux-Hans Driesch. Zur Geschichte der Entwicklungsphysiologie der Tiere, Jena 1974. 
Natomiast monografia tegoż autora pt. Die werdende Form: eine Geschichte der kausualen Morphologie ${ }^{3}$ poświęca Drieschowi sporo miejsca (od 257 do 331 strony) i zawiera istotne odniesienia do badań biologicznych Driescha. Jednakże opisywane analizy naukowe sa wyrwane z szerszego kontekstu badań Driescha i przez to również nie odzwierciedlają one szczegółowych powiązań i relacji metodologicznych oraz ich właściwego kierunku.

Książka Josepha Needhama Chemical Embryology ${ }^{4}$ zawiera pewne odniesienia do badań naukowych Driescha. Stanowią w głównej mierze krytykę entelechii jako czynnika metafizycznego, mającego wyjaśnić swoistość całościowych procesów morfogenetycznych. Dotyczą głównie pewnych aspektów metodologiczno-metafizycznych badań Driescha, z pominięciem szczegółowych analiz jego ujęć metodologiczno-eksperymentalnych ${ }^{5}$.

3 Zob. R. Mocek, Die Werdende Form. Eine Geschichte der kausualen Morphologie, Marburg 1998.

4 Zob. J. Needham, Chemical Embryology, Cambrigde 1931.

5 Należy zaznaczyć, że Driesch w początkowej fazie swoich badań naukowo-eksperymentalnych dążył do ukucia swoistego parametru przyrody, analogicznego do siły grawitacji. Były to więc próby stricte naukowe, ukazujące określoną heurezę badawczą w toku poszukiwań czynnika całościującego. Needham z kolei, w badaniach Driescha, odnosił się tylko do postulatu entelechii w ujęciu czysto metafizycznym. Świadczy o tym to, co pisał na temat entelechii w swojej książce Chemical Embryology. Streszczał badania Driescha w sposób następujący: Driesch przyjmuje niezmienny (niezależny od czynników fizyczno-chemicznych) pierwiastek całościujący, nazwany entelechią - od greckiego terminu oznaczającego coś, co ma ukierunkowanie w sobie, ma cel samo w sobie. Czynnik ten jest rodzajem intensywnej wielorakości w przeciwstawieniu do ekstensywnej (czasowo-przestrzennej) widzialnej wielorakości cech strukturalnych, ujawniającej się w miarę postępowania procesu rozwojowego (embriogenezy). Entelechia ma działać w przestrzeni, ale istnieć całkiem poza przestrzenia, stąd nie może być lokalizowana w żadnym punkcie przestrzeni zajmowanej przez organizm. Działa ona w poszczególnych częściach organizmu, nie ulegajac jednak podziałowi. Entelechia jest pozbawiona cech kwantytatywnych. Oznacza to, że jej wewnętrzna wielorakość nie może być pojmowana tak, jak gdyby jej części znajdowały się w różnych punktach czasoprzestrzeni. W ten sposób Driesch - jak wykazuje Needham - chciał wyjaśnić fakt, że podziały przestrzenne przeprowadzone przez ciało zarodka nie były w stanie zakłócić zdolności entelechii do kierowania harmonijnym rozwojem zarodka. Entelechia nie działa - zdaniem Driescha - jako źródło energii względem cząsteczek materii, ale poprzez ograniczanie czy zawieszanie zakresu ich możliwych reakcji. Por. J. Needham, Chemical Embryology, dz. cyt., s. 1657. 
Z kolei typowa praca dyplomowa (MA) ${ }^{6}$ ogranicza się do pobieżnego przeglądu filozoficznych poglądów Driescha w zakresie jego badań naukowych, traktowanych jednak zupełnie marginalnie, bez szczegółowego omówienia metodologii tych badań. Praca owa zawiera tylko krótki przegląd współczesnych uwag krytycznych odnośnie witalistycznej filozofii Driescha.

Książka Kazimierza Szewczyka Biologia i sens. Studium witalizmu Jacoba von Uexküla ujmuje porównawczo stanowisko Driescha i nawiązuje w wielu punktach kolejnych jej rozdziałów do jego witalistycznej koncepcji. Są to jednak wyłącznie rozważania ogólnofilozoficzne, typu: „Hans Driesch - od teoretycznego egoizmu do problemu Boga”, „Driesch i Uexkül - liniowy postęp wiedzy i koncepcja wiecznego powrotu rzeczy”, „Müller i Driesch - problem stosunku duszy i ciała”, „Hans Driesch - psychoid i entelechia”. Badania te zwracają głównie uwagę na metafizyczne poglądy Driescha, a nie na jego poglądy stricte naukowe.

Praca zbiorowa pod redakcja Aloysa Wenzla Hans Driesch Persönlichkeit und Bedeutung für Biologie und Philosophie von Heute ${ }^{8}$, poświęcona działalności badawczej Hansa Driescha, obejmuje trzy artykuły merytoryczne (nie licząc: biografii, korespondencji Driescha z Prof. Alwinem Mittaschem i przeglądu prac Hansa Driescha). W artykułach tych omawia się głównie prace filozoficzne Driescha oraz znaczenie jego neowitalizmu w wymiarze filozoficznym w jego epoce, jak też charakterystykę sposobu ogólnego określania przez Driescha problematyki biologicznej. W tej ostatniej pracy mamy tylko schematyczną analize pewnych pojęć teoretycznych stosowanych przez Driescha w toku jego badań morfogenetycznych. O jakichkolwiek szczegółowych analizach metodologii badań naukowych Driescha nie ma w ogóle mowy.

${ }^{6}$ Zob. I. Shelley, Hans Driesch and Vitalism. A Reinterpretation, Vancouver 1973.

7 Zob. K. Szewczyk, Biologia i sens. Studium witalizmu Jacoba von Uexküla, Łódź 1993.

8 Zob. A. Wenzl, Hans Driesch Persönlichkeit und Bedeutung für Biologie und Philosophie von Heute, München-Basel 1951. 
Pozostałe prace tematyczne, w których to wspomina się o filozofii Driescha, mają na ogół charakter cząstkowych odniesień do jego rozważań metafizyczno-spekulatywnych. $Z$ reguły nie dotyczą one metodologii ani konkretnych badań naukowych.

W związku z tym można by nawet było mówić o błędach niektórych historyków filozofii i historyków nauki w sposobie ujmowania stanowiska Driescha. Należałoby to jednak rozumieć po prostu tak, że praca Driescha na polu biologii i filozofii bywała czasami mylnie rozumiana jako tylko czysta metafizyka. Przyczyna takiego stanu rzeczy wydają się jednak zbyt fragmentaryczne analizy poszczególnych głównych etapów pracy badawczej Driescha. Przesadnie zwracano uwagę na czasowo późniejszy aspekt metafizyczno-spekulatywny dociekań Driescha, nie dostrzegając lub co najmniej pomniejszając znaczenie o wiele wcześniejszego etapu naukowo-badawczego i metodologiczno-epistemologicznego w praktykowaniu koncepcji witalistycznej przez Driescha w embriologii. Nic więc dziwnego, że takie zawężenie pola analizy w odniesieniu do stanowiska Driescha w konsekwencji mogło doprowadzać do przesadnego uwydatniania jego stanowiska metafizycznego. Trafność takiej diagnozy potwierdzaja, krótko scharakteryzowane powyżej, najważniejsze prace odnoszące się do filozofii Driescha.

\section{O niektórych problemach badawczych wynikających z cząstkowej interpretacji poglądów witalistycznych Hansa Driescha}

Stanowisko witalistyczne Hansa Driescha, jak wykazałem wyżej, jest w główniej mierze opracowywane od strony metafizycznej jego badań. Takie zawężenie pola badawczego często przyczynia się do błędnej oceny i interpretacji jego naukowo rzetelnej i odkrywczej myśli badawczej, wrażliwej na jakościową swoistość zjawisk organicznych w przyrodzie, która to swoistość nie dawała się adekwatnie ująć na gruncie ówczesnego przyrodoznawstwa.

W rzetelnie prowadzonych badaniach naukowych Driescha entelechia (E) była postrzegana przez niego jako swoista dla życia wiel- 


\section{kość parametryczna świata przyrody ${ }^{9}$, a nie tylko i wyłącznie jako}

9 Filozof, zmierzając do przedmiotowego ugruntowania kategorii $E$, przedstawiał badaną ektodermę jako walec, który rozwinięty mógłby stanowić jego płaszcz jako prostokąt o określonych wymiarach $a$ i $b$. Rozważany prostokat w tym kontekście badawczym miał być podstawą normalnego niezakłóconego rozwoju. Driesch, określając jego boki jako pewne miejsca stałe, stwierdzał, że rzeczywista rola znaczenia prospektywnego każdego elementu prostokąta pozostaje w stałej i określonej relacji do długości dwóch linii $x$ i $y$, pod kątem prostym do boków owego prostokąta. Ujmując to w sposób analityczny: każdej możliwej wartości $x$ i $y$ odpowiada całkiem określony, specyficzny stan zróżnicowania, tj. określona możliwość (przeznaczenie), odpowiadająca każdej możliwej wartości $x$ i $y$.

Badania empiryczne oraz osadzone na nich rozważania filozoficzne witalisty miały doprowadzić do wyraźnego rozróżnienia dwóch ważnych pojęć: znaczenia prospektywnego i mocy prospektywnej. Dokładnie chodziło o to, że znaczenie prospektywne elementów badanego organu embrionalnego nie mogło być identyczne z ich moca prospektywna. Moc prospektywna jest o wiele bogatsza, niż wykazywał to określony badany przypadek rozwoju embrionalnego.

Badacz, dochodząc do niezwykle ważnych, ogólnych wniosków badawczych, postawił pytanie o charakterze metodologicznym: od jakich czynników może być uzależnione znaczenie prospektywne (prospektive Bedeutung) $B$ we wszystkich przypadkach oddziaływania (wstrząsania, oddzielania) na element $X$ ? $B(X)=f(\ldots)$

Poszukując brakujących elementów równania matematycznego, filozof z kolei stwierdzał: znaczenie prospektywne elementu $B$ od $X$ jest niewatpliwie funkcja... ale czego?

Wiedział już także, na podstawie przeprowadzanych wcześniej prób eksperymentalnych, że można odciąć którąkolwiek część organizmu i otrzyma się proporcjonalnie kompletny zarodek, chyba że usunięta część jest zbyt dużej wielkości. Oznaczało to jednak, że znaczenie prospektywne każdego elementu na pewno jest od czegoś zależne, czyli na pewno jest funkcją absolutnej wielkości części badanego systemu, istniejącej w danym przypadku. Niech $S$ będzie absolutną wielkością systemu w jakimkolwiek realnym przypadku morfogenezy. Wtedy - uważał Driesch - możemy zapisać równanie w postaci: $B(X)=f(S \ldots)$. Jednakże owemu $S$ będziemy musieli przypisać także inne wielkości.

Z drugiej strony operacja przecięcia w badanym przypadku pozostawała nie tylko w określonej relacji do sumy materiału usuniętego z zarodka, ale także do kierunku jego przecięcia. Oczywiście prawie w każdym realnym przypadku istnieje zarówno określona wielkość systemu, jak i określony kierunek cięcia. Te dwie wartości pozostają zawsze w pewnej relacji ze sobą. Embriolog, w celu zapewnienia niezależności i rzetelności swoich badań dotyczących „,zmiennej kierunku”, podał następujący przykład. Wyobraźmy sobie - pisał - że odizolowaliśmy za pierwszym razem część naszego systemu poprzez linie, a następnie odizolowaliśmy także jednakową część, w przypadku której ograniczenie stanowią linie. Jak się okazuje, w obu przypadkach wynikiem rozwoju może być mały, ale kompletny organizm, dlatego też dostrzega on, że pomimo ich jednakowej wielkości znaczenie prospektywne każdego elementu z obu odciętych zarodków może się zmieniać nawet w relacji do kierunku same- 
go cięcia. Rozważany element $X$ może przynależeć do obu części o równej wielkości, jednakże jego rzeczywiste przeznaczenie mimo wszystko będzie różne.

Analitycznie rzecz biorąc, można by powiedzieć - dowodził dalej Driesch - że to przeznaczenie prospektywne zmienia się w zależności od rzeczywistego miejsca realnych linii granicznych części, czy też ze względu na podstawowe linie kierunkowe lub strony całego prostokata $a, b$. Niechaj to rzeczywiste położenie będzie wyrażone przez literę $l$, przy czym $l$ będzie oznaczało odległość realnej linii granicznej rozważanej części, oznaczonej od $a$ do $b$; wówczas możemy zapisać naszą formułę następująco: $B(X)=f(S, l \ldots)$.

Wyprowadzane równanie nie było jeszcze kompletne. Brakowało w nim najważniejszej wielkości, która miała odgrywać fundamentalną rolę w świecie przyrody ożywionej.

Driesch w toku swoich rozważań analitycznych ustalił, że $S$ i $l$ są wielkościami nazywanymi przez matematyków wartościami zmiennymi. Mogą one mieć pewna faktyczną wartość stała, która będzie określoną wartością $B$ i określonym przeznaczeniem rzeczywistym $X$, którego zależności bada się dla każdej wartości $S$ i $l$. Przy czym wartości $S$ i $l$ miały być od siebie niezależne i miały odpowiadać określonemu znaczeniu prospektywnemu, oznaczonemu litera $X$.

Embriolog ostatecznie wprowadził do swoich badań pewien czynnik kierujący, który - w jego najgłębszym przekonaniu - miał bezpośrednio wpływać na rozwój organizmów oraz został pośrednio ustalony na podstawie jego prac eksperymentalnych. Czynnik ów nie miał być jakaśs zmienna, ale miał być stały we wszystkich przypadkach oddziaływania na organizmy żywe. Obejmować miał także swoim zasięgiem moc prospektywną badanego systemu, choć nie miał być z nią zupełnie identyczny.

W tym ujęciu badawczym moc prospektywna badanego systemu (każdego jego elementu) była sumą tego, co może zostać zrealizowane przez każdy element systemu; fakt, że w każdym możliwym przypadku zachodzi proporcjonalny rozwój typowy, dowodzi jednak tego, że ta suma nie jest tylko prostym dodawaniem, ale przedstawia rodzaj pewnego porządku, który można nazwać: „zależnością umiejscowienia w absolutnie normalnym przypadku”. Należy jednak pamiętać, że określenie „moc prospektywna” lub owa względna proporcjonalność, stanowiąca podstawę do nazwania badanego systemu harmonijnym, zawsze powinna go współokreślać; wówczas możemy stosować owo wyrażenie bez dalszych wyjaśnień terminologicznych do oznaczenia niezmiennego czynnika, od którego zależy znaczenie prospektywne każdego elementu. Jeżeli oznaczymy porządek obejmujący moc prospektywną literą $E$, to jesteśmy w stanie uzupełnić nasze wyrażenie i zapisać je w postaci: $B(X)=f(S, l, E)$.

Powyższe szczegółowe rozważania dają odpowiedź na pytanie, co miała oznaczać Drieschowa stała wielkość $E$, która z czasem została nazwana entelechia, interpretowaną metafizycznie. W zamyśle badacza nie oznaczała ona rezultatu wynikającego z jakiegokolwiek układu; nie była ona krótszym określeniem dla skomplikowanego stanu rzeczy. $E$ wyrażała nowy, istotny, stały element przyrody.

Takie właśnie ujęcie rozumiem jako wysunięty przez Driescha postulat uznania istnienia swoistego parametru przyrodniczego dla zjawisk organicznych i życia w ogóle. W jego świetle życie, a przynajmniej morfogeneza, nie jest jakimś szczególnym układem zdarzeń nieorganicznych. Dlatego też biologii nie należy redukować do fizyki 
osobliwa „substancjalna” forma bytu pozaprzestrzennego, rozumianego w ujęciu metafizycznym ${ }^{10}$.

Driesch w jednym z listów do Alwina Mittascha pisał, że samo tradycyjne pojęcie tzw. witalizmu woli określać mianem doktryny o autonomii życia ${ }^{11}$. Oznacza to, że jego stanowisko witalistyczne zachowywało, w istotnej mierze, fundamentalny wymiar metodologiczny typu naukowo-badawczego. W kolejnym liście do Alwina Mittascha z końca lat trzydziestych XX wieku, a więc tuż przed śmiercia, objaśniając sens określenia „mechanicyzm”, Driesch stwierdził expressis verbis, że podobnie jak pojęcie entelechii traktuje to określenie jako termin czysto techniczny, operacyjny, stosowany w toku badań ściśle naukowych ${ }^{12}$. Oznacza to z kolei wyraźne zdystansowanie się Driescha, przynajmniej werbalne, do jego własnego stanowiska metafizycznego na rzecz naukowego wymiaru jego pracy badawczej.

Oddzielne analizowanie pojęć filozoficzno-metafizycznych Driescha (entelechia, psychoid etc.) oraz separowanie ich od pojęć bezpośrednio opartych na jego badaniach embriologicznych jest jedna z głównych przyczyn niejasności i błędnych interpretacji jego wielostronnie i w pełni rozwiniętego stanowiska witalistycznego. Chodzi przede wszystkim o to, że współcześni badacze, głównie historycy

i chemii. Życie jest czymśs samym dla siebie, a biologia jest niezależną nauką podstawowa. Por. D. Szkutnik, In Search of the Specific Parameter of Life-General Methodological Comments, „Biocosmology-neo-Aristotelism” 6 (2016) nos. 3\&4, s. 453-464.

10 Drieschowi w przypadku samych eksperymentalnych badań embriologicznych nie chodziło bynajmniej o entelechię rozumianą wyłącznie metafizycznie, jako jakaśs rzekomo nową odmianę „bytu” w stosunku do obiektów i zjawisk fizykochemicznych i ich właściwości, ale o entelechię rozumianą w sposób czysto poznawczy i badawczy, a więc epistemologiczno-metodologiczny. Tak bowiem jak w fizyce i chemii siła, energia, masa itp. nie są jakimiś „bytami” metafizycznymi w stosunku do konkretnych obiektów i zjawisk fizycznych i chemicznych, ale są ich obiektywnymi i uniwersalnymi parametrami przyrodniczymi, ściśle mierzalnymi i w konkretnych swych wartościach w pełni przewidywalnymi, tak entelechia miała być - wedle intencji badawczych Driescha - swoistym parametrem przyrodniczym świata organicznego. Por. H. Driesch, Die Organischen Regulationen, Leipzig 1901, s. 170-182. Por H. Driesch, Philosophie des Organischen, Leipzig 1921, s. 116.

11 Zob. A. Wenzl, Hans Driesch..., dz. cyt., s. 181.

12 Zob. A. Wenzl, Hans Driesch..., dz. cyt., s. 184. 
nauki, często zapominają o samej wartości heurystycznej szczegółowych pojęć stricte naukowych ukutych przez Driescha w toku jego pracy analitycznej, opartej na wcześniej zgromadzonym materiale empirycznym. Mam na myśli pojęcia ważne do dzisiaj dla biologii rozwoju ${ }^{13}$, takie jak: „moc prospektywna” ${ }^{14}$, „znaczenie prospektywne" 15 oraz ,system harmonijno-ekwipotencjalny" ${ }^{16}$.

Na ogół jest jednak tak, że artykuły naukowe i opracowania filozoficzne skupiające się na filozofii Driescha pomijają szczegółowy opis jego metod eksperymentalnych, które już na początku były prawdopodobnie inspirowane intuicjami witalistycznymi; stanowiły także podstawę do przezwyciężenia redukcjonizmu mechanicystycznego w biologii. Odpowiednio ukierunkowane podejście badawczo-eksperymentalne Driescha do wyselekcjonowanego materiału biologicznego skutkowało tym, że badacz ostatecznie wyciagną wniosek, iż mechanistycznie myślaccy August Weismann mylił się, przynajmniej częściowo, a eksperyment Wilhelma Roux, mający na celu znalezienie odpowiedzi na pytanie, czy podział zygoty na dwie komórki jest równocześnie podziałem „programu” rozwojowego na dwie części, był źle pomyślany i dał błędny wynik ${ }^{17}$.

13 Por. K. Ostrowski, Embriologia człowieka, Warszawa 1985, s. 82.

14 Pojęcie mocy prospektywnej (prospektive Potenz) oznaczało możliwy los każdego z elementów żywego organizmu. Por. H. Driesch, Philosophie des Organischen, dz. cyt., s. 66 .

15 Określenie „znaczenie prospektywne” (prospektive Bedoutung) oznaczało w biofilozofii Driescha rzeczywisty los każdej embrionalnej części w określonym procesie morfogenetycznym. Por. H. Driesch, Philosophie des Organischen, dz. cyt., s. 66.

16 We współczesnej biologii rozwoju pojęcie „system harmonijno-ekwipotencjalny” często jest zastępowane pojęciem „system totipotencjalny”. Osobliwość systemów harmonijno-ekwipotencjalnych polegała na tym, że każdy z ich elementów mógł pełnić dowolną funkcję w ramach całokształtu procesów, który występuje w całości systemu. Do takiej to roli odnosiło się także Drieschowe określenie „funkcja położenia”. Driesch nazywał swoje systemy także „systemami ekwipotencjalnymi z poszczególnymi potencjami” albo krócej: „systemami jednostkowo-ekwipotencjalnymi”. Przy tym należy pamiętać, że moc prospektywna każdego elementu embrionalnego jest stała oraz że jego możliwa wartość jest zmienna. Dlatego też w toku eksperymentów Driescha rozwój grupy komórek blastuli jeżowca morskiego zawsze przebiegał w odniesieniu do całości organizmu, ponieważ ukierunkowany był przez moc prospektywna. Por. H. Driesch, Philosophie des Organischen, dz. cyt., s. 112.

17 Zob. R. Mocek, Die Werdende Form..., dz. cyt., s. 282-289. 
Na uwagę zasługuje fakt przeciwstawienia się Driescha tendencjom mechanistycznym. W przeciwieństwie do programu mechanistycznego Driesch stanął zdecydowanie na gruncie zasady autonomii życia w stosunku do świata nieorganicznego oraz autonomii biologii względem fizyki i chemii, uznając biologię za naukę przyrodniczą równie elementarna jak fizyka ${ }^{18}$. Opozycję wobec tendencji redukcjonistycznych (oraz wskazanie na szczególne cechy metodologiczne układów żywych: całościowy charakter badanych zjawisk i ich zasadniczą niepodzielność) można (z dzisiejszej perspektywy) uznać za niewątpliwą zasługę Driescha. Biologia - jak niektórzy twierdzili ${ }^{19}$, co podkreślał z oburzeniem Driesch ${ }^{20}-\mathrm{w}$ pewnym sensie nie jest niczym innym niż stosowaną fizyką i chemią.

Witalistycznie inspirowana metoda eksperymentalna Driescha, praktykowana przez niego na dwu- i czterokomórkowych zarodkach jeżowca w celu stworzenia identycznych bliźniąt i czworaczków, staje się poznawczo owocna i śmiało można założyć, że była pierwszą udana próbą klonowania organizmu zwierzęcego z pojedynczych komórek ${ }^{21}$.

Można powiedzieć - jak sądzę - że Driesch stworzył także podwaliny tzw. medycyny regeneracyjnej, ponieważ odkrył, że zarodkowe komórki macierzyste mają nietypową zdolność do regeneracji i replikowania się w nieskończoność. Potrafią także przekształcać się w każdy rodzaj komórek organizmu (są totipotencjalne) ${ }^{22}$. W zależności od otrzymywanych informacji mogą stać się mięśniami, skóra, krwią etc. Z komórek macierzystych są wytwarzane inne komórki, które są w stanie naprawiać i regenerować uszkodzone lub starzejące się tkanki.

18 Zob. H. Driesch, Die Biologie als selbständige Grundwissenschaft und das System der Biologie. Ein Betrag zur Logik der Naturwissenschaften, Leipzig 1911, s. 19.

19 Także dzisiaj, por. B. O. Küppers, Leben $=$ Physik + Chemie? Das Lebendige aus der Sicht bedeutender Physiker, München 1987.

20 Zob. H. Driesch, The Science and Philosophy of the Organism, vol. I, London 1908, s. 9-12.

21 Zob. I. Wilmut, K. Campbell, C. Tudge, Ponowny akt stworzenia. Dolly i era panowania nad biologia, tłum. M. Koraszewska, Poznań 2002, s. 90.

22 Totipotencjalność, ekwipotencjalność rozwojowa, omnipotencjalność - zdolność komórek do różnicowania się w dowolny rodzaj komórek (zygota, blastomery, komórki interstycjalne, komórki macierzyste, każda żywa komórka roślinna). 
Z kolei brak wyraźnego ukazania metodologii badawczej Driescha w zakresie czynności naukowo-poznawczych, a także opisowo-porównawczych stosowanej w toku jego badań empirycznych skutkuje w efekcie tym, że współcześni badacze filozofowie często odrywaja metafizyczne ujęcie pojęcia entelechii od czynności eksperymentalnych, praktykowanych w rzeczywistości przez embriologa na organizmach zwierzęcych. Dlatego też owi badacze zapominaja, że dzieło przezwyciężenia materializmu Driesch rozpoczął ze stanowiska biologa, zmierzając konsekwentnie w kierunku metafizyki ${ }^{23}$. Owocem tej swoistej wędrówki analitycznej było m.in. porzucenie przezeń wąskiego zapatrywania mechanistyczno-redukcjonistycznego, opartego głównie na pojęciu substancji fizyko-chemicznych ${ }^{24}$, w zakresie wyjaśniania złożoności i osobliwości świata organicznego ${ }^{25}$.

\section{Podsumowanie}

Na podstawie przeanalizowanego materiału badawczego dotyczącego opracowań stanowiska witalistycznego Hansa Driescha i w świetle faktu, że ich autorzy, poruszający się w zakresie owej tematyki, zajmuja się głównie jej aspektami metafizycznymi, należy podkreślić, co następuje.

Konieczne jest, z jednej strony, bardziej dogłębne rozważenie wymiaru ściśle naukowego badań morfogenetycznych Driescha - wprawdzie o tyle, o ile inspirowane one były pewnymi pojęciami metafizycznymi, ale o ile także zarazem zastosowano je do uwydatnienia przyrodniczej swoistości życia.

$\mathrm{Z}$ drugiej zaś strony byłoby wskazane dogłębne przebadanie implikacji teoretycznych i wpływów metodologicznych, które wynikają z owych ściśle naukowych dokonań i osiagnięć Driescha w odnie-

${ }^{23}$ Zob. K. Szewczyk, Biologia i sens..., dz. cyt., s. 40.

24 Por. H. Driesch, Die matematisch-mechanische Betrachtung morphologischer Probleme der Biologie. Eine kritische Studie, Jena 1891.

25 Nie opisuję tutaj zderzenia się stanowiska mechanistycznego ze stanowiskiem neowitalistycznym ze względu na ograniczoną objętość niniejszego artykułu. Kompleksowe omówienie tej tematyki wymagałoby osobnego opracowania. 
sieniu do różnych działów biologii współczesnej. Niesłusznym jest bowiem pogląd głoszacy, że Hans Driesch w ogóle nie był naukowcem i co więcej - że jego wnikliwe obserwacje i spostrzeżenia oraz oparte na nich pomysły badawcze, także te eksperymentalne, sąjuż dzisiaj nikomu niepotrzebne.

\section{Summary}

On the present research contain the point of view about the neovitalistic conception of Hans Driesch's. General critical remarks

Achievements of Hans Driesch (1867-1941), German embryologist and philosopher, are contemporarily viewed almost exclusively from their later metaphysical phase of development, while his earlier scientific experimental researches are not appreciated sufficiently enough. They consisted in highlighting the specifically totipotential character of biological, and especially of embryological, processes what is still methodologically inspiring in many dimensions of contemporary biological investigations. The author postulates thus a deeper analysis of Driesch's scientific accomplishments and broader assessment of their actual significance in contemporary biology.

Keywords: Hans Driesch, vitalism science, embryology, biology, metaphysic, totipotential

\section{Bibliografia}

Driesch H., Die Biologie als selbständige Grundwissenschaft und das System der Biologie. Ein Betrag zur Logik der Naturwissenschaften, Leipzig 1911.

Driesch H., Die matematisch-mechanische Betrachtung morphologischer Probleme der Biologie. Eine kritische Studie, Jena 1891.

Driesch H., Die organischen Regulationen. Vorbereitungen zu einer Theorie des Lebens, Leipzig 1901.

Driesch H., Philosophie des Organischen, Leipzig 1921.

Driesch H., The Science and Philosophy of the Organism, vol. I, London 1908.

Freyhofer H., The Vitalism of Hans Driesch. The Success and Decline of a Scientific Theory, Frankfurt am Main 1982. 
Küppers B. O., Leben = Physik + Chemie? Das Lebendige aus der Sicht bedeutender Physiker, München 1987.

Mocek R., Die Werdende Form. Eine Geschichte der Kausalen Morphologie, Marburg 1998.

Mocek R., Wilhelm Roux - Hans Driesch. Zur Geschichte der Entwicklungsphysiologie der Tiere, Jena 1974.

Needham J., Chemical Embryology, Cambridge 1931.

Ostrowski K., Embriologia człowieka, Warszawa 1985.

Shelley I., Hans Driesch and Vitalism. A Reinterpretation, Vancouver 1973.

Szewczyk K., Biologia i sens. Studium witalizmu Jacoba von Uexkülla, Łódź 1993.

Szkutnik D., In Search of the Specific Parameter of Life - General Methodological Comments, „Biocosmology-neo-Aristotelism” 6 (2016) nos. 3\&4, s. 453-464.

Wenzl A., Hans Driesch Persönlichkeit und Bedeutung für Biologie und Philosophie von Heute, München-Basel 1951.

Wilmut I., Campbell K., Tudge C., Ponowny akt stworzenia. Dolly $i$ era panowania nad biologia, tłum. M. Koraszewska, Poznań 2002. 